Volume 3, No. 2 Januari 2020

\title{
PENGARUH PENGGUNAAN MEDIA GAMBAR TERHADAP KEMAMPUAN MEMBACA SISWA LAMBAT BELAJAR
}

\author{
SUGIHARTATIK \\ IKIP PGRI JEMBER \\ tatik.khodijah.misnati.com@gmail.com
}

\begin{abstract}
Abstrak
Penelitian ini bertujuan untuk mengetahui pengaruh penggunaan media gambar terhadap kemampuan membaca siswa lambat belajar kelas III di SDN Patrang I Jember . Penelitian ini dilakukan mulai tanggal 1 Oktober - 15 Oktober 2019. Dengan menggunakan teknik Quota Random Sampling dengan mengambil sampel penelitian sebanyak 7 siswa lambat belajar dari 37 siswa dalam satu kelas. Data diperoleh dengan metode tes, observasi, dan dokumentasi selanjutnya data yang diperoleh dianalisis menggunakan statistic moment. Hasil analisis = 0,996, Sedangkan tabel harga kritik untuk N=7. Taraf signifikansi $5 \%-0.754$, Taraf signifikansi $1 \%=0.874$. Karena hasil hitungan lebih besar dari kedua harga kritiknya maka Ho harus ditolak dan Ha diterima. Hasil dari penelitian ini membuktikan bahwa penggunaan media gambar memberikan pengaruh yang signifikan dalam meningkatkatkan motivasi belajar membaca bagi siswa lambat belajar di kelas III SDN Patrang I Jember.
\end{abstract}

Kata Kunci: Media gambar, membaca, siswa lambat belajar

\begin{abstract}
This study aims to determine the effect of the use of picture media on the reading ability of students of slow learning class III at SDN Patrang I Jember. This research was conducted from October 1 to October 15, 2019. Using the Quota Random Sampling technique by taking a sample of 7 students slow learning from 37 students in one class. Data obtained by the method of test, observation, and documentation then the data obtained were analyzed using statistical moments. The analysis results $=0.996$, while the criticism price table for $N=7$. Significance level 5\%-0.754, Significance level 1\% $=0.874$. Because the result of the calculation is greater than the two prices of the criticism, Ho must be rejected and Ha accepted. The results of this study prove that the use of image media has a significant influence in increasing the motivation to learn to read for students who are slow in class III at SDN Patrang I Jember.
\end{abstract}

Keywords: Image media, reading, students are slow to learn

\section{PENDAHULUAN}

Tujuan akhir dari proses pendidikan adalah adanya perubahan tingkah laku dari peserta didik dan peserta didik mengalami perkembangan yang lebih baik dari semua aspek http://doi.org/10.31537/speed.v3i2.276 perkembangan, terutama perkembangan koqnitif. Berawal belum tahu menjadi tahu, dan dari tidak bisa menjadi bisa, dan semua hal tersebut Dengan tujuan tersebut diatas maka siswa dituntut untuk dapat membaca, maka dengan kemampuan membaca tersebut cakrawala berfikir siswa dapat 
berkembang sehingga memungkinkan siswa lebih mudah dalam memahami semua mat pelajaran. Menurut (Lerner, 1988, hlm. 89).

Keterampilan membaca sangat diperlukan bagi semua siswa, termasuk siswa yang mengalami hambatan dalam perkembangannya, Membaca adalah jendela dunia, maka dengan kemampuan membaca siswa dapat memperluas cakrawala berfikirnya, untuk lebih mudah memahami mata pelajaran yang diajarkan Guru.

Pada dasarnya kemampuan membaca adalah sebuah ikatan organik yang berproses secara alamiah sejalan dengan perjalanan hidup siswa. Namun kenyataan di lapangan ditemukenali terdapat 7 siswa yang terdeteksi mengalami hambatan perkembangan dalam belajar mengalami kesulitan dalam membaca dan memaknai huruf, kata dan kalimat.

Siswa yang terdeteksi mengalami lambat belajar tidak tergolong tuna grahita, karena hal ini dibuktikan dengan tes IQ mereka antara 70-90. Berdasarkan identifikasi dan asesmen kesulitan siswa dalam membaca ini dipengaruhi oleh beberapa faktor, baik itu faktor internal maupun faktor eksternal dari diri siswa itu sendiri. salah satu faktor internal dari dalam siswa antara lain konsep negatif dalam memandang dirinya. yaitu perasaan tidak berdaya dan merasa bodoh kenapa hal ini bisa terjadi karena disebabkan faktor eksternal dari orang tua, teman sebaya maupun orang tua yang memberikan label negatif pada http://doi.org/10.31537/speed.v3i2.276 siswa yang mengalami hambatan dalam belajar.

Dengan kesulitan membaca tersebut siswa lambat belajar akan semakin merasa putus asa dalam mempelajari mata pelajaran lainnya. Kondisi demikian membuat orang tua dan guru memberikan tekanan, dan hal itu akan membuat orang tua merasa gelisah, dan akhirnya orang tua memberikan tekanan-tekanan pada anaknhya dengan memaksa anaknya belajar membaca melalui les tambahan baik di sekolah maupun les tambahan di rumah, dan fatalnya lagi metode pengajaran membaca yang diberikan guu kelas maupun guru kelas, monoton tidak variatif dan membosankan.

Maka dari itulah orang tua dan guru harus lebih kreatif dalam mengajarkan membaca pada siswa yang terdeteksi mengalami hambatan dalam membaca. Sebaiknya kata-kata yang digunakan saat mengajari siswa membaca adalah kata-kata yang dekat dengan kehidupan siswa misalnya dengan memberikan konsep bacaan tentang nama sendiri, berlanjut nama kedua orang tua, anggota keluarga dan teman-teman dekatnya, kemudian ditingkatkan dengan memahami konsep bacaan tentang mainan kesukaan atau hewan peliharaan yang juga dekat dengan kehidupan siswa dengan menggunakan media gambar atau foto agar lebih nyata, dan mudah diingat oleh siswa.

Kreatifitas dalam memberikan konsep membaca pada siswa lambat 
belajar bisa menggunakan media gambar berupa foto maupun gambargambat yang menarik lainnya yang ditempelkan di karton dengan disertakan tulisan dibawah gambar tersebut sesuai ukuran karton mulai dari ukuran yang besar, sedang dan kecil agar siswa belajar membaca lebih termotivasi, mudah mengingat dan menyenangkan..

\section{METODE PENELITIAN}

Penelitian ini dilaksanakan di SDN Patrang I Jember. yang dilaksanakan pada bulan Oktober hingga November. Subyek penelitian berjumlah 7 siswa, empat siswa berjenis kelamin laki-laki dan tiga siswa berjenis kelamin perempuan. Adapun Desain penelitian ini menggunakan One Group Desain, Eksperimen dilakukan dengan meneliti kemampuan membaca masing-masing siswa tanpa media gambar (Y) kemudian meneliti kemampuan masingmasing siswa dengan media gambar (X ). Adapun desain penelitian sebagai berikut :

$\mathrm{T} 1 \mathrm{X} \mathrm{T} 2$

Variabel yang digunakan adalah variabel bebas dan variabel terikat, variabel bebasnya atau variabel penyebab dari variabel yang terikat yaitu penggunaan media gambar. Sedangkan variabel terikatnya atau variabel yang tergantung pada variabel yang mendahului yaitu kemampuan membaca siswa lambat belajar kelas III SD untuk mengetahui seberapa besar akibat yang ditimbulkan atau yang diperoleh karena adanya pengaruh dari variabel bebas.

Teknik pengambilan sampel yang digunakan adalah Quota Random Sampling. Dengan menentukan terlebih dahulu sejumlah anggota sampel secara quantum (jatah) dengan menggunakan Quota Random Sampling tersebut maka dihasilkan sampel siswa lambat belajar Polulasi yang digunakan dalam jumlah ini adalah seluruh siswa lambat belajar di Kelas berjumlah 7 orang. 4 siswa berjenis kelamin laki-laki yaitu (BZ, AG, MJ, WS) sedangngkan siswa lambat belajar berjenis kelamin perempuan berinisial (AR, BK dan LCM)

Dalam penelitian ini mengunakan analisis secara statistic, yaitu teknik analisis statistic dengan menggunakan statistic Product Moment, dengan menggunakan rumus :

$$
r_{x y}=\frac{\sum x . y}{\sqrt{\left(\sum x^{2}\right)\left(\sum y^{2}\right)}}
$$

Keterangan

$\mathrm{R} x \mathrm{y}=$ Product Moment

$\mathrm{XY}=$ Gejala $\mathrm{x}$ dan gejala $\mathrm{y}$

\section{HASIL DAN PEMBAHASAN}

Hipotesis kerja (Ha) ada Pengaruh penggunaan media gambar terhadap kemampuan membaca siswa 
lambat belajar di kelas III di SDN Patrang I Jember

Hipotesis Nihil (H0) tidak ada Pengaruh penggunaan media gambar terhadap kemampuan membaca siswa lambat belajar di kelas III di SDN Patrang I Jember

Menurut Natawidjaja dkk Media adalah alat bantu atau pelengkap yang digunakan guru untuk dapat berkomunikasi dengan siswa. Sedangkan Gambar menurut H.S Sastro Carito dalam Kamus Bahasa Indonesia “ Gambar adalah tiruan gambar berupa orang, tumbuhan atau binatang yang dibuat dengan cat, tinta potret dan lainlain. Secara operasional media gambar adalah alat bantu berupa tiruan gambar (orang, binatang, tumbuhan) yang digunakan guru dalam proses pembelajaran atau interaksi guru dalam berkomunikasi dengan siswa.

Sedangkan menurut DR Oemar Hamalik dalam bukunya yang berjudul media pendidikan, gambar adalah sesuatu yang diwujudkan secara visual dalam bentuk dua dimensi sebagai curahan perasaan atau pikiran, berupa lukisan, ilustrasi, karikatur, kaligrafi, kartun, poster, gambar seri, potret, dan slide. Secara operasional media gambar adalah segala alat fisik yang diwujudkan secara visual dalam bentuk dua dimensi sebagai curahan perasaan atau pikiran, berupa lukisan, ilustrasi, karikatur, kaligrafi, kartun, poster, gambarseri, potret, dan slide.untuk merangsang minat siswa dalam membaca.
Menurut Abdurahman (1999) Media gambar memiliki beberapa kelebihan antara lain:

1. Gambar dapat mengatasi batasan ruang dan waktu, karena tidak semua benda, objek ataupun peristiwa dapat di bawa ke kelas dan siswapun tidak bisa dibawa langsung ke obyek atau peristiwa tersebut.

2. Gambar dapat mengatasi keterbatasan pengamatan kita karena dapat menghadirkan halhal yang mungkin tidak dapat di tangkap oleh penglihatan.

3. Gambar dapat memperjelas suatu masalah , murah harganya, mudah didapat dan tidak memerlukan peralatan khusus untuk menggunakannya.

Membaca merupakan salah satu jenis kemampuan berbahasa tulis yang bersifat reseptif. Disebut reseptif karena dengan membaca seseorang akan memperoleh informasi, ilmu pengetahuan, dan pengalamanpengalaman baru. Semua yang diperoleh melalui bacaan itu akan memungkinkan orang tersebut mampu mempertinggi daya pikirannya, mempertajam pandangannya, dan memperluas wawasannya. Dengan demikian maka, kegiatan membaca merupakan kegiatan yang sangat diperlukan oleh siapa saja yang ingin maju dan meningkatkan diri. Oleh karena itu, pembelajaran membaca di sekolah mempunyai peranan yang pentinng. 
Dalam pembelajaran membaca, sebaiknya guru mengajarkan kata-kata yang dekat dengan kehidupan siswa, misalnya dengan memberikan konsep bacaan tentang namanya sendiri, berlanjut nama kedua orang tua, anggota keluarga dan teman-teman dekatnya, kemudian ditingkatkan dengan memahami konsep bacaan tentang mainan kesukaan atau hewan peliharaan yang juga dekat dengan kehidupan siswa dengan menggunakan media gambar atau foto agar lebih nyata, dan mudah diingat oleh siswa.

Selanjutnya guru dapat mengembangkannya dengan memilih wacana-wacana yang berkaitan dengan tokoh nasional, kepahlawanan, kenusantaraan, dan kepariwisataan. Selain itu melalui contoh pembelajaran membaca, guru dapat mengembangkan nilai-nilai moral, kemampuan bernalar, dan kreativitas siswa

Media pembelajaran adalah segala sesuatu yang dapat digunakan untuk merangsang pikiran, perasaan, perhatian, dan kemauan siswa didik sehingga dapat mendorong terjadinya proses belajar pada diri siswa ( Miraso dalam Asep Herry Hernawan, 2008: 11 ). Perbedaan gaya belajar, minat, intelegensi, keterbatasan daya indra, hambatan jarak geografis dapat diatasi dengan pemanfaatan media pembelajaran.

Ada berbagai cara yang dapat digunakan guru dalam mengatasi kesulitan belajar membaca salah satunya, yaitu dengan menggunakan media gambar. Agar perhatian siswa lebih terfokus dan tertarik pada mata pelajaran, dan juga akan memberikan pengalaman yang nyata. Sehingga dapat membantu para siswa untuk lebih mudah dan cepat dalam belajar membaca

- Menurut penelitian terdahulu, media yang paling tepat digunakan adalah media gambar. Karena media gambar merupakan media pandang dua dimensi yang dirancang secara khusus untuk mengkomunikasikan pesan pembelajaran (Winataputra, 2006, hlm. 5.3). Penggunaan media ini diharapkan dapat membantu siswa agar lebih mudah dan berhasil dalam belajar membaca permulaan di kelas III SD.

Ada tiga komponen yang perlu dipahami dalam keterampilan membaca yaitu :

a. Komponen pertama yaitu mengenalkan konsep tanda baca yang disesuaikan dengan mode membentuk garis- garis, titik-titik dalam hubungan pola yang teratur

b. Komponen kedua yaitu, mengenalkan konsep mengkorelasi aksara beserta tanda-tanda baca dengan unsur-unsur linguistik yang formal. Yaitu keterampilan menghubungkan titik-titik hitam diatas kertas membentuk gambar berpola.

c. Ketiga, menanamkan keterampilan intelektual yaitu menghubungkan tanda- 
Volume 3, No. 2 Januari 2020

tanda hitam diatas kertas melalui unsur-unsur bahasa yang formal, yaitu kata-kata yang bermakna ( Broghton (et all) 1998, hlm. 72)

Aspek yang pertama adalah, keterampilan yang bersifat mekanis (mechanical skill) yang mencakup tentang keterampilan dalam mengenal bentuk huruf, pengenalan unsur-unsur linguistik ( fonem, suku kata, morfem, kata, frase, klausa dan kalimat. pengenalan hubungan atau korespondensi pola ejaan dan bunyi atau kemampuan menyuarakan bahan tertulis ( to bark of print) dan kecepatan membaca bertaraf lambat.

Aspek yang kedua adalah keterampilan yang bersifat pemahaman (comprehension skills) yang mencakup aspek keterampilan memahami pengertian sederhana (leksikal, gramatikal, retorikal), selanjutnya adalah keterampilan dalam memahami signifikansi atau makna dari penulisan (isi dan bentuk) dan kecepatan membaca yang fleksibel dan mudah disesuaikan dengan keadaan (Broughton (et all) 1998, hlm. 73)

Hal yang perlu diperhatikan dalam kegiatan mengajar membaca pada siswa lambat belajar adalah : Media yang digunakan hendaknya mudah dipahami oleh siswa lambat belajar, . Konsep-konsep yang terkandung di dalamnya merupakan konsep yang hidup dalam pikiran siswa, kata-kata yang digunakan mudah dimengerti oleh siswa secara logis dan kosa kata atau kalimat yang ditulis dibawah gambar disesuaikan ukurannya dengan media gambar yang berukuran besar, sedang dan kecil.

Menurut Mulyadi, (2010, hlm. 123) siswa yang mengalami kesulitan dalam belajar adalah siswa yang perkembangan belajarnya lebih lambat dibandingkan dengan perkembangan rata-rata teman seusianya. dan memiliki kecerdasan dibawah rata-rata.

Siswa yang lambat belajar adalah siswa yang memiliki prestasi rendah dan dibawah rata-rata pada salah satu kemampuan akademik (membaca) atau seluruh kemampuan akademik (membaca, menulis maupun berhitung), siswa yang mengalami lambat belajar memiliki skor IQ antara 70-90 jadi siswa lambat belajar bukan termasuk siswa tunagrahita.

Siswa lambat belajar membutuhkan pelayanan khusus dari seorang guru yaitu dengan waktu yang lebih banyak untuk memahami konsepkonsep pelajaran yang diajarkan oleh guru dikarenakan daya tangkap yang dimiliki siswa lambat belajar adalah rendah.dan memilik konsep diri yang rendah, mudah menyerah untuk belajar sesuatu yang dianggapnya sulit

Desiningrum (2016, hlm. 11) mengemukakan bahwa ada beberapa faktor yang menyebabkan siswa lambat belajar diantaranya adalah faktor biokimia yang dapat merusak otak, salah satu contohnya adalah zat pewarna makanan yang biasa dikosumsi siswa disekolah dan tersedia di kantin sekolah, 
sedangkan makanan atau cemilan yang terkontaminasi zat pewarna atau pengawet tersebut selalu dikonsumsi siswa secara berkelanjutan di setiap harinya dalam kurun waktu yang panjang selama siswa berada di sekolah,.didukung pula oleh gizi yang tidak seimbang dan memadai yang disajikan orang tua di rumah semakin berdampak kurang baik pada perkembangan koqnitif siswa lambat belajar.

\section{PENUTUP}

\section{Simpulan}

\begin{abstract}
Berdasarkan hasil penghitungan dapat disimpulkan bahwa ada peningkatan kemampuan membaca untuk siswa lambat belajar kelas III Di SDN Patrang I Jember, setelah mendapatkan stimulasi penuh dari guru dengan kesabaran dan konsistensi yang berkelanjutan dan bertahap dalam belajar membaca menggunakan media gambar.
\end{abstract}

\section{Saran}

1. Diharapkan guru memiliki kreatifitas untuk mencari bahan dalam penggunaan media gambar dari berbagai media cetak maupun media online dan tidak hanya terpaku hanya pada buku paket.

2. Diharapkan guru dapat menciptakan model pembelajaran yang dapat merangsang minat membaca bagi siswa lambat belajar karena kemampuan membaca merupakan dasar utama untuk menguasai berbagai bidang studi.

3. Diharapkan pihak sekolah menenamkan minat baca pada semua siswa termasuk siswa lambat belajar dengan menggalakkan perpustakaan sekolah yang representatif.

\section{DAFTAR PUSTAKA}

Abdurrahan, Mulyono. (1999).

Pendidikan Bagi Siswa Berkesulitan Belajar Jakarta.Rineka Cipta

Ashman, A \& Elkins, J. Education Childreen With Special Needs. New York : Prontice Hall

Hamalik, Oemar. (1989). Media Pendidikan Bandung PT Citra Aditya Bakti

Kartadinata, S (2002) Pengembangan Perangkat Lunak Analisis Pengembangan Siswa Dalam Upaya Peningkatan Mutu Layanan Dan Manajemen Bimbingan Dan Konseling di Sekolah. Laporan Riset Unggulan Terpadu VII, Bandung Fakultas Ilmu Pendidikan Indonesia

Tambubalon. (1993). Mengembangkan Minat Dan Kebiasaan Membaca Pada Siswa Bandung Angkasa 
Volume 3, No. 2 Januari 2020

http://doi.org/10.31537/speed.v3i2.276 